sciendo

\section{CAPABILITIES SELECTED RULES, RECOMMENDATIONS AND PROBLEMS FOR THE DESIGN OF POWER ELECTRONICS EQUIPMENT INSTALLED ON SHIPS}

DOI 10.2478/ntpe-2018-0090

\author{
dr inż. Adam Muc \\ dr hab. inż. Piotr Mysiak \\ dr inż. Andrzej Kasprowicz \\ Gdynia Maritime University, Poland
}

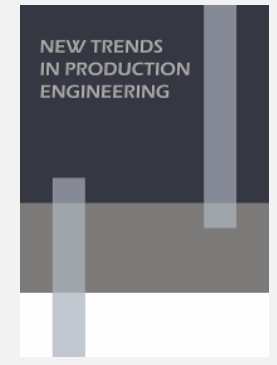

2018

Volume 1

Issue 1

pp. $711-720$

\begin{abstract}
The paper presents an analysis of the state and possibilities of using power electronics and electric drives on ships, and in particular, in ship engine room. Problems related to the operation of power electronics in the soft network are presented. The issues related to the design of multi-pulse high power rectifiers are discussed, which is one of the most popular power electronics devices used on vessels. Then a simulation study of selected rectifier circuits was carried out. The purpose of this study was to show the effect of selecting a power electronics design on the waveforms of the voltages and currents in a soft network on the rectifier example. Also discussed are main electromagnetic device problems and issues related to regulations and recommendations for their design and operation. Proper selection of the type of the power supply design and observance of the rules and regulations ensures the efficiency of the equipment and the quality of the energy being processed and reduces their negative impact on the remaining equipment and network.
\end{abstract}

Keywords: power electronics, electric drive, engine room, high power converters, electricity conditioning

\title{
INTRODUCTION
}

Currently, highly specialized power electronics systems are installed on board marine vessels at an increasingly higher rate, and at a broader spectrum. They also appear as the solution where, up until now, the unrivalled solution has been a combustion-based system. This mainly refers to the main drive of the vessel. Service analysis has shown that in many cases they are better than the classic - with internal combustion engine installed until now. Apart from this, a main drive with an electric motor together with a power system is much more efficient within the entire output power range and rotation speed. At the same time, alongside the tendency of replacing the combustion engine with an electric motor, there is a division of power generating on a few generators in order to increase the reliability of the drive system.

Diesel generator sets with synchronous generators produce electrical power to meet the demands of the electric drive system. Depending on the power of the drive system, the generators output voltage varies from $3.3 \mathrm{kV}$ to $6.6 \mathrm{kV}$, and recently may even reach a value of $11 \mathrm{kV}$. The generators' high voltage output is used to decrease the value of current when dealing with high power, as it simplifies switching processes and limits power losses. The high voltage is not used for powering devices - it is rectified. For such purpose, uncontrolled rectifiers are used. They operate in various connection systems at a high voltage input and output. In some cases, to decrease the voltage, 3-phase transformers are used. Simultaneously applied connection systems of transformers enable phase shifting in multi-pulse rectifiers supplying voltages. These rectifiers are better able to smoothen the direct current, which is the power source for inverters. These in turn, power the alternating current motors of ship main drives, thrusters. Well-smoothened direct current has a lesser impact on the work of the supplied systems. To ensure safety, main switchboards - installed on board vessels, are divided into two sections. This enables the redundancy of power (siemens.com, 2017). 
In most cases voltage inverters with pulse width modulation are used to supply the vessel's main motors with power. In the case of smaller capacities, with the main bus bar voltage of $440 \mathrm{~V}$, these can also be two-level inverters. For capacities at the level of kilovolts, it is common to apply multilevel inverters. They are characteristically highly-complicated, with complex control.

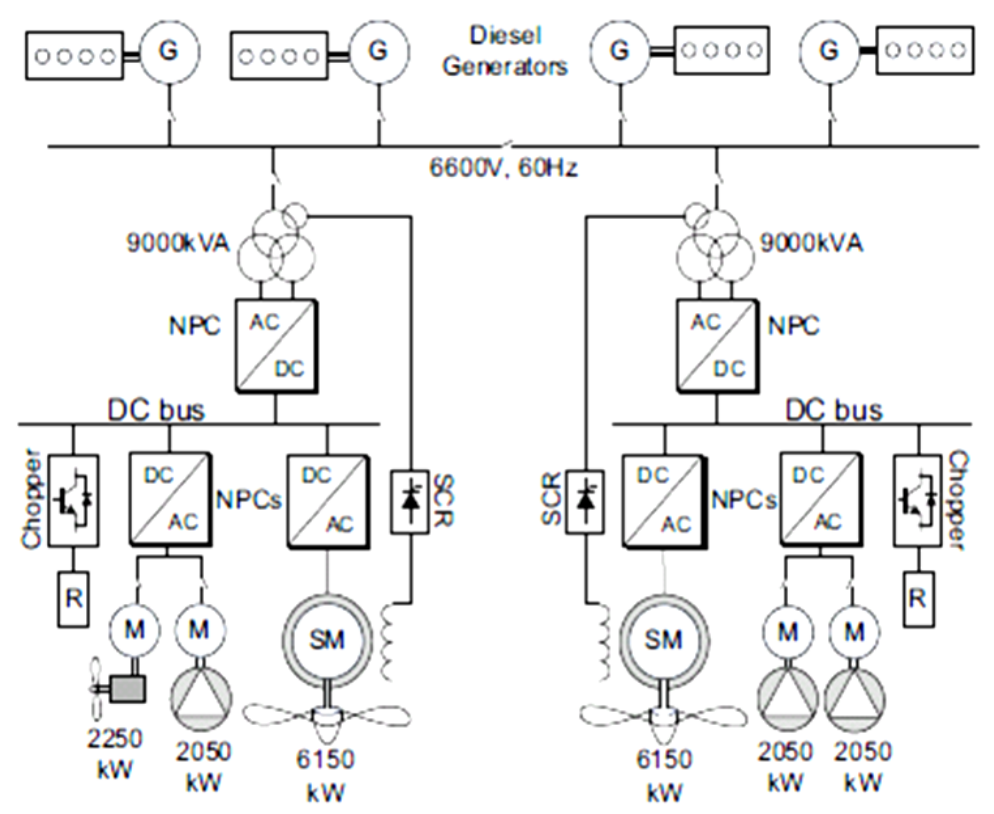

Fig. 1 Tanker Vessel Main Drive Power System With Back-to-Back Redundancy Source: (siemens.com, 2017), (Kouro S. et al., 2010)

An example diagram of electric main-drive is presented in Figure 2.

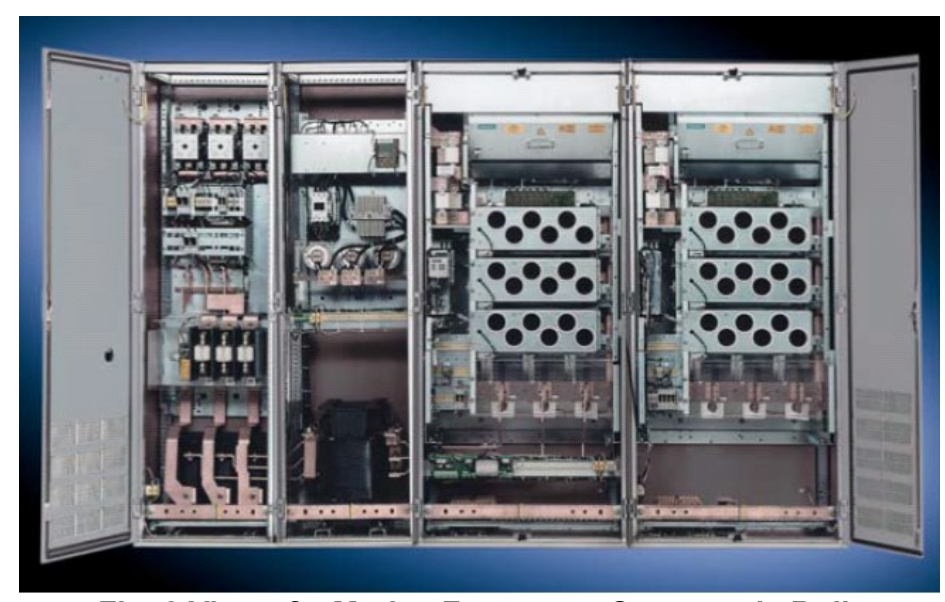

Fig. 2 View of a Marine Frequency Converter's Built

Source: (Javaid U. et al., 2015)

Generators supply a voltage of $6.6 \mathrm{kV}$. Voltage-reducing transformers in the system reduce the voltage that is then smoothen in the process. It powers NPN (Neutral Point Clamped) multilevel inverters. The main drive motors are powered with the modulated voltage output. The vessel's other large-capacity devices are powered with the use of similar inverters (Kouro S. et al., 2010). The final element of a vessel drive is a high-capacity electric motor. Currently there are three types of alternating current motors. A synchronous motor is the basic unit. It however requires an additional source of direct current for the excitation circuit. The motors are slow-rotating, with a rated speed of 150-200 rpm and a very high power capacity, of the scale of a few megawatts. The inverters powering these motors provide the possibility to control the rotation speed from zero to the rated speed with a rated electromagnetic torque. A small rated motor speed enables eliminating from a drive system a gear, which is characterized by its large size and weight. The gear is also a very unreliable element in the drive track. As inverters allow a fluent regulation of 
rotation speed from zero to the rated speed, drive systems are built with fixed-pitch blade propellers. Additionally, another important issue is the installation of a short shaft connecting the motor with the propeller.

The motor is connected with the power source by means of electric cables. This provides large flexibility while installing them in an engine room - in turn, the available space inside the compartment is adopted more effectively. A properly located motor and properly located devices reduce noise and vibrations (Fig. 3).

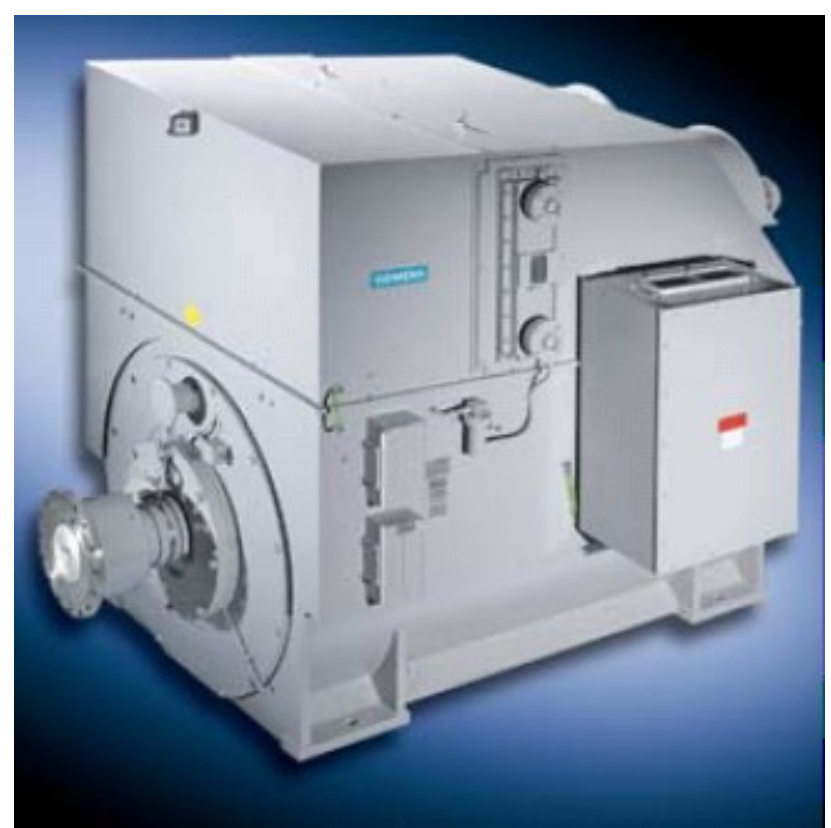

Source: (Javaid U. et al., 2015)

Fig. 3 A Marine Vessel's Main Drive Electric Motor

A cheaper solution is to install an asynchronous motor in the place of a synchronous one. It is characterized by a more simple construction, high reliability and a smaller cost. Other elements in the system installation do not change.

Permanent magnet synchronous motors are also used. This however, is the most expensive solution due to the use of permanent magnets made of rare earth elements.

An electric main drive, regardless of the installed motor, is characteristically highly vulnerable to control - which results in a very good maneuvering ability of a vessel. Due to the applied redundancy, there is also very little chance of complete loss of drive power. An electric drive system is also characteristic for very high dynamics and high torque developed at a very low rotation speed of a motor (siemens.com, 2017), (Javaid U. et al., 2015).

Unfortunately, in order to achieve the goals mentioned above, very advanced technology needed to be applied. This involves high costs of implementation. Problems with interference emitted into the network occur during the work of high-power converters. High torque harmonics are generated in converter-powered machines. Step changes in voltage with a very high climb factor $\mathrm{dU} / \mathrm{dt}$ occur on the side of the converters' output. This is a very serious risk to the motor's isolation. Apart from this, bearing currents may occur, resulting in grinding pits in the bearing runners. In the long run, these lead to damage. The possibility of such a situation's occurrence demands special preventive constructions. Current harmonics occurring in the work of electric power devices demand the use of appropriate motor power supply cables, passive filters and active filters which improve the shape of electric current charged from the vessel's Active Front End network (Kouro S. et al., 2010), (Javaid U. et al., 2015).

SIMULATION RESEARCH OF MULTI-PULSE RECTIFIERS

One of the most frequently applied power electronics devices are rectifiers, which are used as either power systems or AC/DC converters used by other electric power devices - such as inverters. Uncontrolled diode rectifiers are commonly applied due to their small costs, high 
reliability, and a low emission of electromagnetic interference. Despite the simple construction of traditional 6-pulse rectifiers, multi-pulse rectifiers' construction is usually complicated, and demands complex control systems. Therefore, increasing the amount of pulses by complicating a rectifier's construction results in the improvement of the output voltage and current shapes, but only up until a certain point. This rule does not present a linear increase, as increasing the number of pulses over 32 is not adequate with resulting quality of effects.

Figures 4 to 9 present example diagrams of electric power systems. The level of complication in their construction and the results of simulations are different. The first system researched in the simulation is a traditional 6 -pulse $20 \mathrm{~kW}$ rectifier, connected to a soft electric power network (Figure 4).

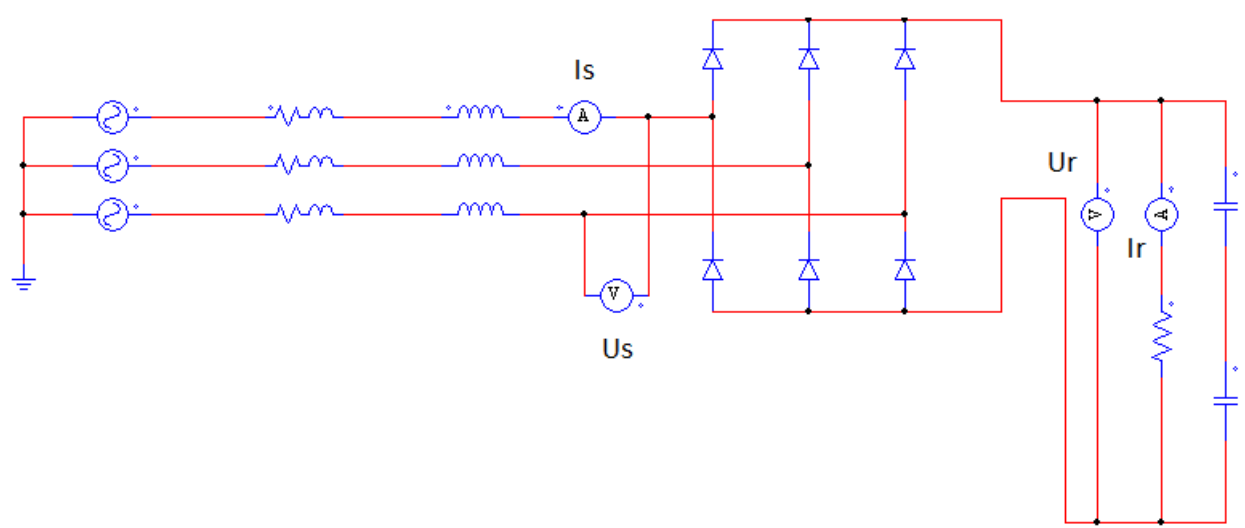

Fig. 4 Diagram of a 6-pulse 20kW Rectifier Connected to a 3-phase Electric Power Network Source: Author's research

Impedance representing cable network connections has been placed between the voltages of the network and the rectifier, which in turn was loaded with resistance. Figures 5 and 6 present examples of voltage and current curves registered at the entry point of the rectifier and its load.

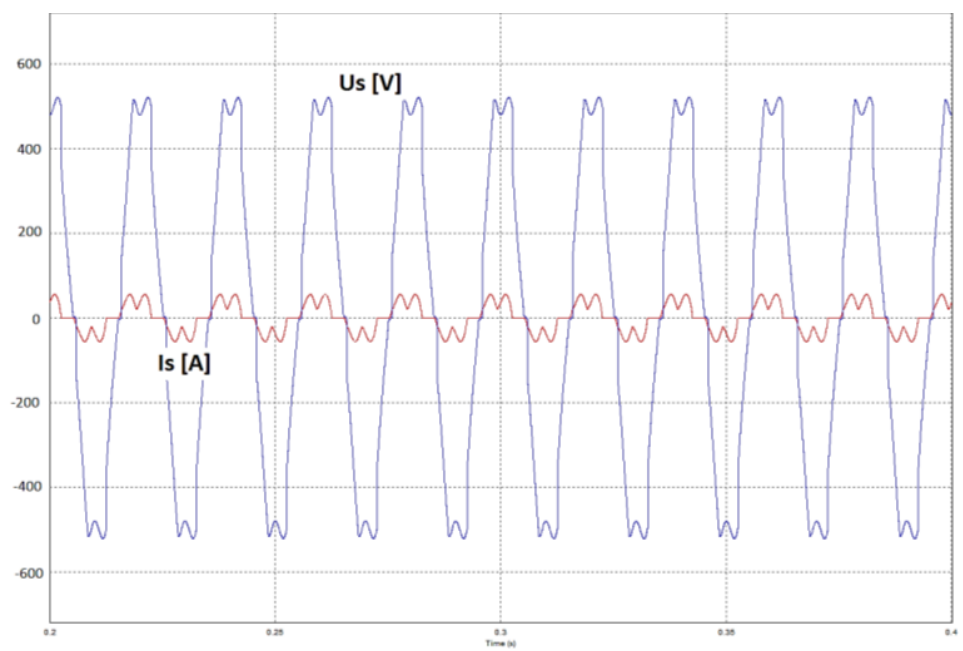

Fig. 5 Network Voltage (Us) and Current (Is)

Curves at the Entry Point of a 6-pulse Rectifier Author's research 


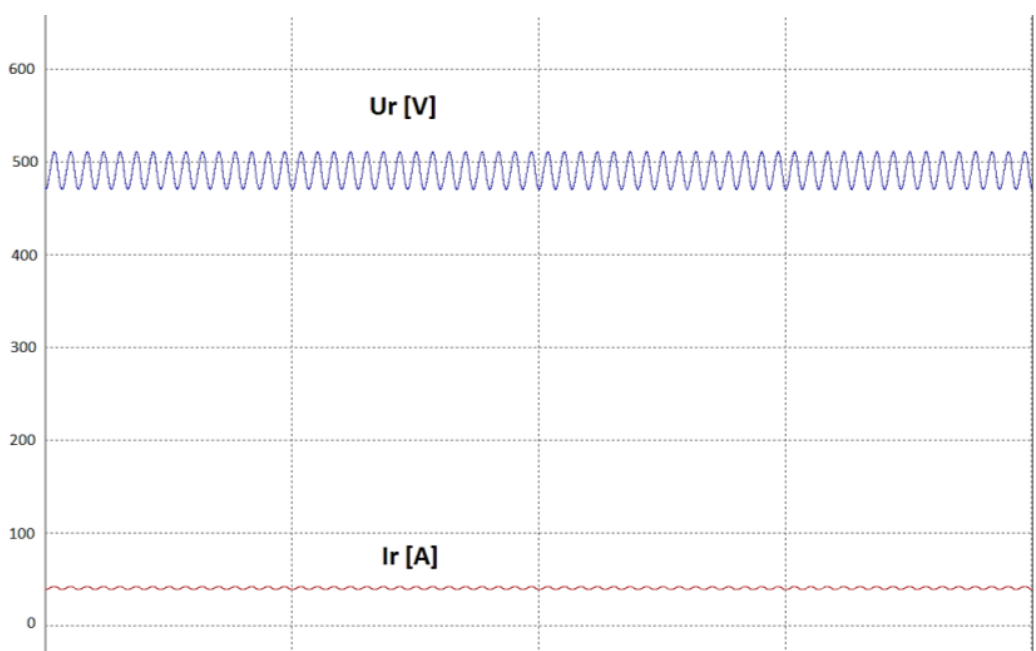

Fig. 6 Voltage (Ur) and Current (Ir) Curves for the Load Connected to a 6-pulse Rectifier Author's research

Even while analysing the voltage and current diagrams at the entry and exit points of the rectifier alone, its detrimental activity to the soft grid and load can be observed. The voltage and electric current at the entry point of the rectifier should have a sinusoidal characteristic, however, as it can be seen from illustration 5 , this is not so. The Us voltage and Is current contain-harmonics. Illustration 6 on the other hand presents voltage at the exit point to not be ideally rectified, but to have a pulsatile characteristic.

In order to compare the construction and functioning of rectifiers, illustration 7 presents another diagram of this type of device with the same power, but this time of a 18-pulse type.

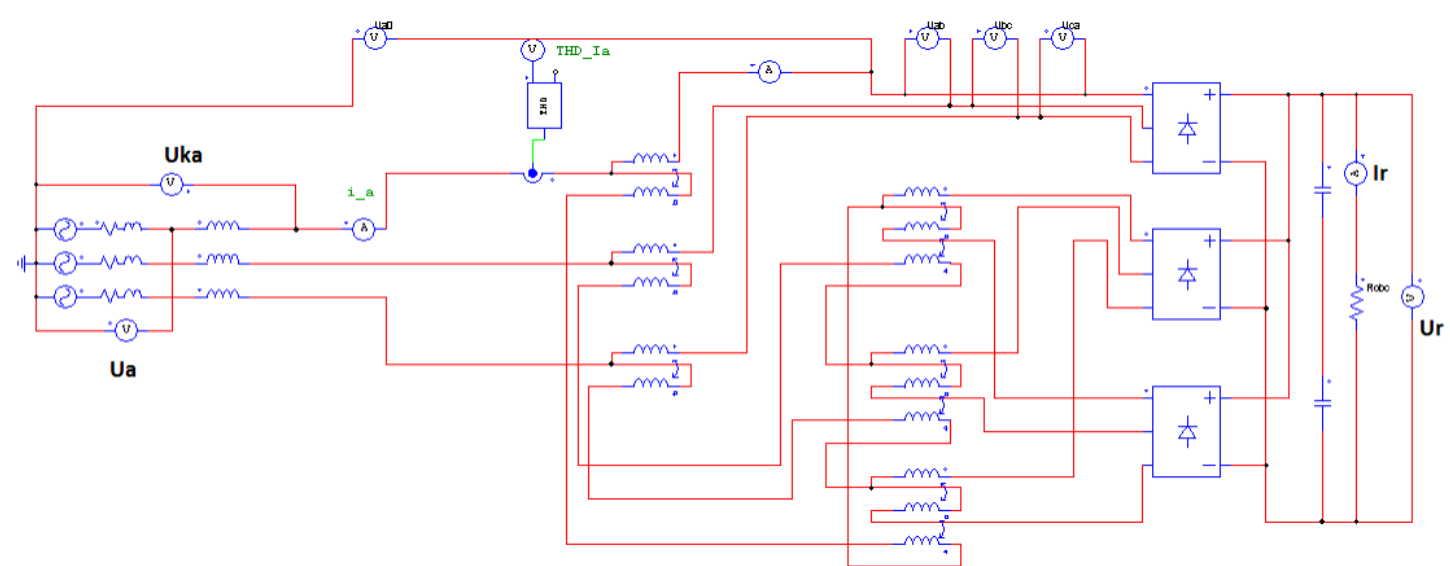

Fig. 7 Diagram of a 18-pulse 20 kW Rectifier Connected to a 3-phase Electric Power Grid Author's research

The work principle of an 18-pulse rectifier is the generating of three 3-phase voltage systems, shifted from one another at an angle of $20^{\circ}$ and powering 6-pulse diode rectifiers. Mutual displacement of 3-phase systems is accomplished by means of an initial power distribution WPP reactor and a set of 3-phase TDS $\lambda$ coupled reactors (Wasiluk W., 2007). Such construction of a rectifier enables a radical limitation of power currents harmonics, mainly of type 5, 7, 11 and 13. Figure 8 presents example voltage (Uka) and current (la) diagrams registered at the exit point of an artificial grid, which was constructed at the need of constructing an 18-pulse rectifier. 


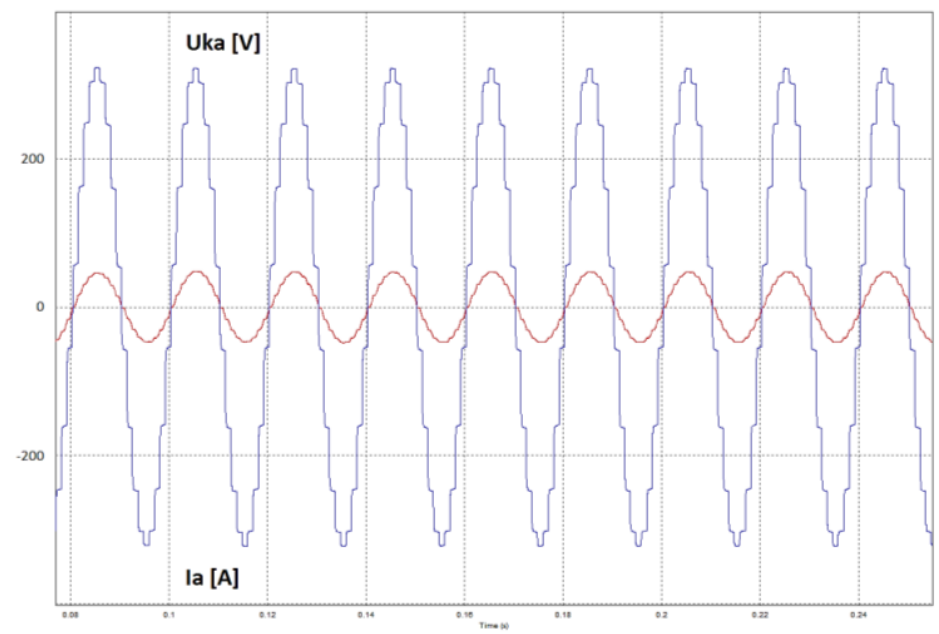

Fig. 8 Voltage Curves (Uka) and Current Curves (la) Registered at the Exit Point of an Artificial Grid in Front of an 18-Pulse Rectifier Author's research

Figure 9 on the other hand, presents example voltage (Ur) and current (Ir) diagrams registered on the load added to the rectifier.

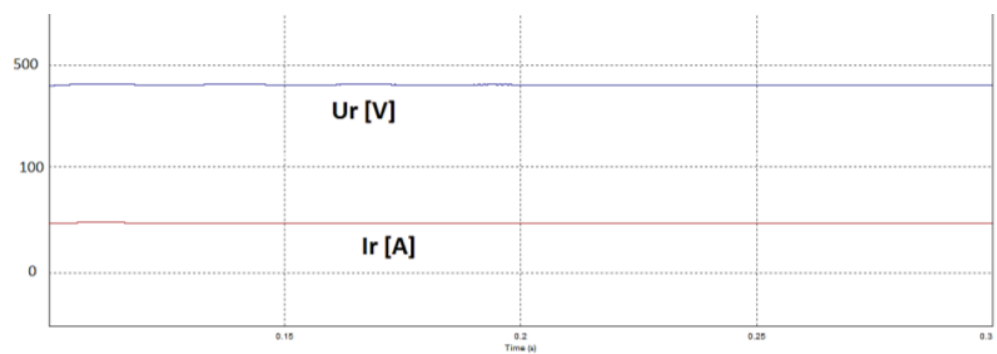

Fig. 9 Voltage Curves (Ur) and Current Curves (Ir) for the Load of a Connected 18-Pulse Rectifier Author's research

The curves in Figure 9 present an improvement of output voltage and current, achieved in the exit point of the 18-pulse rectifier. A similar improvement was observed for the voltage and current registered at the entry point of the rectifier (Fig. 8).

\section{SELECTED REGULATIONS AND RECOMMENDATIONS CONCERNING THE CONSTRUCTION OF POWER ELECTRONICS DEVICES}

Power electronics devices are characteristic for a complex construction, which constitutes of a control system and frequently of a few circuits of a highly varied level of voltages and electric currents. The control algorithm, which is very often applied by means of microprocessors, is also a very important element of the device. In general case, in every power electronics device there is at least one power circuit, and one electronics circuit (Barlik R., 1998), (Mysiak P., 2010).

The power circuits (main), apart from buses and connecting cords, include the following:

- An appropriately connected set of semi-conductor power devices, equipped with safety devices protecting against short-circuits, power spikes and overloads. The set may also include commutation circuits.

- Entry circuits, containing a converter transformer or network reactors, coupled magnetic elements, connection apparatus (contactors, breakers), short-circuit protection devices and anti-interference filters.

- voltage type connection circuits (capacitors) or current type connection circuits (reactors)

- Exit circuit, containing connection apparatus, exit filters, fuses and such.

Electric power circuits include circuits of small capacity, designated for control, signalization, diagnostics and measuring. A cooling system has an important role in electric power devices. 
Designing a high-power converter is a complex task (Barlik R., 1998), (Mysiak P., 2010). It is necessary to consider all requirements and assumptions regarding the receiver, powering, work conditions of the device itself, and the possibility of control (PN-IEC 146-1-1-1), (PN-IEC 146-11-2), (PN-EN 61204). The following elements must be especially paid attention to:

- new characteristics and anticipated effects (benefits in comparison to the current state, recognition of such state).

basic static and dynamic characteristics (information for the potential receiver).

- powering conditions (network, accumulator batteries) and EMC impact on the network.

work safety and comfort

- maintenance and air conditioning conditions (temperature range of work, humidity, altitude)

reliability (application demands) (Mysiak P., 2010), (Mysiak P. et al., 2016).

The main issue with designing can be boiled down to analysis of assumptions, requirements, and possible solutions affordable in the current state of technology. The optimum is sought according to the criteria of: costs, reliability, and weight and dimensions.

The basic task that need to be solved may be formulated as follows:

- selection of elements and protection

- design of control system and monitoring

- construction design with the consideration of heating conditions and electromagnetic compatibility.

The following engineering methods will find application in the design process:

- analytical calculations based on general formulas

- simulations (providing detailed solutions without generalisations)

- laboratory research

The complex completion of a project may be divided into four phases:

1. Formulating of aim and assumptions

2. Introductory design

3. Detailed design of a prototype, construction and research

4. The perfection of the product in the prototype series phase and normal application

The key issue solved while designing is the selection of elements and subsystems in such a way, that the temperature in all systems does not exceed the allowed level, which is set based on the physical characteristics of the materials which are used for the construction of the systems (Wasiluk W., 2007), (Barlik R., 1998).

The regulations and recommendations concerning the construction of electric power devices, especially in the area of fire safety, isolation coordination and amount of housing protection result from general norms regarding the majority of electric power devices (PN-IEC 60364-551), (PN-IEC 60364-5-53), (PN-IEC 664-1). Every electric power device must be constructed and installed in such a way, that none of the parts accessible for the operators present a hazard of an electric shock while operated during normal work conditions and in emergency modes. In the case of electric power devices this concerns the converter housing (locker construction), and loading system of the device powered by the one in question. Alternating current of effective value exceeding $25 \mathrm{~V}$ and direct current exceeding $60 \mathrm{~V}$ is considered as hazardous.

In accordance with regulations preventing shock injuries from electric power devices, means of basic safety, damage protection and simultaneous protection - means of enhanced protection - are applied (PN-IEC 60364-5-51), (PN-IEC 664-1). The necessity of locating conducting elements within housing protected at level no lower than IP20 is one of the specific requirements regarding power electronics devices. The doors of the housing locker should be equipped with a lock, and switches disconnecting the converter from the network, once they are opened.

Means of indirect protection (additional) must complete their tasks in events of damaging the work isolation, and the presence of voltage on the device's housing elements. Their operation is either immediate shut-down of the device by itself, or lowering the contact voltage present on the accessible conducting elements of the device to the level at which it is not a threat of shock. The ruling norm (PN-IEC 60364-5-51), as a basic means of additional protection, recommends the immediate shut-down of the contact voltage, substituting the currently applied zeroing and grounding. 
Meeting the demand of protection against indirect contact in regard to power electronics devices is connected with application of electric shock protection switches, residual current devices, local equalizer connections, and additional isolation filling in work isolation. The housing, whose elements are separated by means of double galvanic isolation from conductor elements of the converter, are not required to be equipped with additional means of electric shock prevention safety elements.

The proper operating of an power electronics device guaranteed by its manufacturer is possible with the fulfillment of according conditions. They mainly concern the environment where the device is to be operated, quality of the feeder line and the level of electromagnetic interference influencing the converter. At the same time, the device should not be inconvenient in operating and should not have any negative impact on the work of other technical - most of all electric devices. Compatibility is defined as the mutual fitting of power electronics devices to the environment and technical conditions. Compatibility may be separated into that of environmental (technological - climatic), compatibility with feeder lines, and electromagnetic compatibility. A properly designed device should meet all compatibility demands in the mentioned areas (PNIEC 146-1-1-1), (PN-EN 61204), (PN-IEC 60364-5-51).

\section{CONCLUSIONS}

Implementing various norms in the dynamically developing branch of electrotechnology, just as in every other branch of technology, conditions the fulfillment of the mentioned above demands. Up until the end of March 2011 SEL - Electrics Sector was responsible for dictating the norms in Electric industry. Since 1st of April 2011, after the definition of electrotechnology, the Sector of Electrotechnology (SET) was established. It is led by 9 Technological Committees.

In the recent years serious changes have been introduced into Polish norms. They specifically refer to the strict connection of the national with international and European norms (Nartowski Z., 2004). The changes are directly linked to Poland's membership in the European Union. Normalization is a broad activity - of a global scale. It conditions the economical development and is directly linked with technological progress and its popularization.

The knowledge of parameters and properties of elements creating a converter and the principles of the work of converter systems, in connection with information concerning the functioning of components and control structures, as well as the characteristics and properties of objects powered by converters, is a vital condition for the proper design and construction of a specific electrotechnical device, its proper operating, and correct repair. In order to create a fully functioning and properly constructed apparatus or device, it is necessary to consider knowledge and abilities in construction technology of individual components, such as converters, control system and additional circuits (such as safety circuits or filters), but most of all in the connection of all the components into a whole, so that they fully complete their planned function while working in the real environment.

\section{REFERENCES}

siemens.com, (2017). The guide of Marine Frequency Converters, Siemens AG, Automation and Drives, Large Drives, Marine Equipment, Postfach 4743, 90441 NÜRNBERG, FEDERAL REPUBLIC OF GERMANY, www.siemens.com/[Accessed 5 March 2017].

Kouro S., Malinowski M., Gopakumar K., Pou J., Franquelo L. G., Wu B., Rodríguez J., Pérez M. A., Leon J. I. (2010): Recent Advances and Industrial Applications of Multilevel Converters, IEEE Transactions on Industrial Electronics (Vol.: 57, Issue: 8, Aug. 2010) pp. 2553-2580, DOI: 10.1109/TIE.2010.2049719, ISSN: 0278-0046, E-ISSN: 1557-9948.

Javaid U., Dujić D., van der Merwe W. (2015). MVDC marine electrical distribution: Are we ready?, Industrial Electronics Society, IECON 2015 - 41st Annual Conference of the IEEE, 9-12 Nov. 2015, Yokohama, Japan, DOI: 10.1109/IECON.2015.7392201, E-ISBN: 978-14799-1762-4, USB-ISBN: 978-1-4799-1761-7.

Wasiluk W. i inni (2007), Poradnik inżyniera elektryka T. 1, 2, WNT, Warszawa.

Barlik R., Nowak M. (1998), Poradnik inżyniera energoelektronika, WNT, Warszawa.

Mysiak P. (2010), Wielopulsowe prostowniki diodowe z dławikami blokującymi wyższe harmoniczne prądu, Wydawnictwo Akademii Morskiej w Gdyni, Gdynia. 
PN-IEC 146-1-1-1 Przekształtniki półprzewodnikowe. Przekształtniki o komutacji sieciowej. Wymagania ogólne.

PN-IEC 146-1-1-2 Przekształtniki półprzewodnikowe z komutacją zewnętrzną. Ogólne wymagania i badania.

PN-EN 61204 Zespoły prostownikowe bezpieczne. Ogólne wymagania i badania.

Mysiak P. i inni (2016), Experimental Test Results of the 150kVA 18-Pulse Diode Rectifier with Series Active Power Filter, CPE-POWERENG'2016, 6th International Conference on Power Engineering, Energy and Electrical Drives, 10th International Conference on Compatibility and Power Electronics, Bydgoszcz, 29.06. 2016 - 01.07. 2016.

PN-IEC 60364-5-51 Dobór i montaż wyposażenia elektrycznego. Postanowienia ogólne.

PN-IEC 60364-5-53 Aparatura łączeniowa i sterownicza.

PN-IEC 664-1 Koordynacja izolacji w instalacjach niskiego napięcia z uwzględnieniem odstępów izolacyjnych powietrznych i powierzchniowych dla urządzeń.

Nartowski Z. (2004), Normalizacja w Elektryce, Biuletyn Techniczny Oddziału Krakowskiego SEP, nr 24.

Date of submission of the article to the Editor: 06/2018

Date of acceptance of the article by the Editor: 09/2018 